\title{
WORZ, INC. v. FCC-A NEW RULE OF PROCEDURE IN TELEVISION LICENSING
}

The Communications Act of 1934 gives the Federal Communications Commission wide discretion in awarding licenses to operate television stations; its basic mandate is that the Commission act in accordance with the "public interest, convenience, and necessity." 1 The Commission's discretion under the public interest standard extends to the formulation of the procedure for licensing proceedings as well as to the formulation of policy, except where a specific procedure is ordered by the statute. ${ }^{2}$ Recently, however, this discretion has been circumscribed by a rule developed by the Court of Appeals for the District of Columbia Circuit. The development of this rule, its nature, and its implications raise interesting questions concerning the scope of review of the Commission's procedural decisions and the proper distribution of functions between the Commission and the court.

The procedure developed by the Commission for the award of a license begins with the filing of an application for an available channel in a particular location. After the first application has been accepted by the Commission, anyone else interested in securing a license for the same channel in the same area may file a competing or "mutually exclusive" 3 application at any time until one day before the Commission takes formal action on the first application, but not less than thirty days after public notice has been made of its acceptance. ${ }^{4}$ While the length of the period for the filing of competing applications is not set by statute or regulation, normal practice seems to allow a year or two in the case of new stations before the original applications will be acted upon. ${ }^{5}$ After the record has been closed to the filing of new applications, those which have been submitted are set for a comparative hearing, ${ }^{6}$ in which an examiner determines whether or not each applicant meets legal, technical, and financial qualifications. ${ }^{7}$ Then, if more than one applicant is qualified the examiner makes

1 Communications Act of 1934, §309(a), 74 Stat. 889 (1960), 47 U.S.C. $\$ 309$ (a)

2 FCC v. Schreiber, 381 U.S. 279, 289-91 (1965) ; FCC v. Pottsville Broadcasting Co., 309 U.S. 134, 138 (1940). (1965)

3 Ashbacker Radio Corp. v. FCC, 326 U.S. 327 (1945); 47 C.F.R. $\$ 1.572(d)$

4 Communications Act of 1934, § 309(b), 74 Stat. 890 (1960), 47 U.S.C. § 309(b) (1964); 47 C.F.R. $\$ 1.227$ (b), 1.571(c), $1.572(\mathrm{e}), 1.591$ (b) (1965).

5 In WORZ, Inc. v. FCC, 345 F.2d 85 (D.C. Cir.), cert. denied sub nom. MidFlorida Television Corp. v. FCC, 86 Sup. Ct. 180 (1965), the first application was received in July, 1952, and the applications were designated for hearing in June, 1954. In Jacksonville Broadcasting Corp. v. FCC, 348 F.2d 75 (D.C. Cir.), petitioner's petition for cert. dentied sub nom. Jacksonville Broadcasting Corp. v. Florida-Georgia Television Co., 86 Sup. Ct. 186 (1965), intervenor's petition for cert. denied sub nom. Florida-Georgia Television Co. v. FCC, 86 Sup. Ct. 186 (1965), the first application was received in 1952, 348 F.2d at 76, and the hearing was opened in February, 1954. City of Jacksonville, 12 Radio Reg. 113, 118 (1956).

647 C.F.R. \& 1.572 (d) (1965).

7 See, e.g., WORZ, Inc., 22 F.C.C. 1254 (1957). 
findings as to their qualifications in each of several areas. He sets out these findings in a report and makes an initial decision ${ }^{8}$ based on the relative qualifications of the applicants. This report constitutes the record in the case, ${ }^{9}$ upon which the Commission, taking into account the hearing examiner's recommendations, reevaluates the applications according to the comparative criteria and makes the award..$^{10}$ The award, unless appealed, is final and confers operating privileges for a three year period, subject to renewal. ${ }^{11}$ Appeals from Commission awards are taken to the Court of Appeals for the District of Columbia Circuit, ${ }^{12}$ which is governed in its review ${ }^{13}$ by section $10(\mathrm{e})$ of the Administrative Procedure Act. ${ }^{14}$ If the court finds error in the making of the award and reverses, it remands the case for a new award. Section 402(h) of the Communications Act provides that on remand the Commission is to act on the old record, except as otherwise ordered by the court. ${ }^{15}$ Apparently acting under authority implicit in section $402(\mathrm{~h}),{ }^{16}$ the court of appeals has recently developed what seems to be a rule governing procedure on remand in certain cases which requires that under some circumstances the Commission must reopen the record for new hearings and for the acceptance of applications from anyone who might wish to apply. The development of this rule leaves a considerable question as to what these circumstances are.

This procedure has been applied in three cases concerning licensing awards: Sangamon Valley Television Corp. v. United States, ${ }^{17}$ WORZ, Inc. v. FCC, ${ }^{18}$ and Jacksonville Broadcasting Corp. v. FCC. ${ }^{19}$ The award

847 C.F.R. $\$ 1.267$ (1965).

947 C.F.R. $\$ 1.203(1965)$.

1047 C.F.R. \& $1.282(1965)$.

1147 C.F.R. $\$ 73.60$ (1965).

1266 Stat. 718 (1952), 47 U..S.C. $\$ 402$ (b) (1964).

1366 Stat. 720 (1952), 47 U.S.C. \& 402 (g) (1964). (1964)

14 Administrative Procedure Act $\S 10(\mathrm{e}), 60$ Stat. 243 (1946), 5 U.S.C. $\S 1009(\mathrm{e})$

15 In the event that the court shall render a decision and enter an order reversing the order of the Commission, it shall remand the case to the Commission to carry out the judgment of the court and it shall be the duty of the Commission, in the absence of the proceedings to review such judgment, to forthwith give effect thereto, and unless othercerise ordered by the court, to do so upon the basis of the proceedings already had and the record upon which said appeal was heard and determined.

66 Stat. 720 (1952), 47 U.S.C. \$ $402(\mathrm{~h})$ (1964). (Emphasis added.)

${ }_{16}$ Cf. Pinellas Broadcasting Co. v. FCC, 230 F.2d 204, 212 (D.C. Cir.) (Bazelon, J., dissenting), cert. denied, 350 U.S. 1007 (1956).

17294 F.2d 742 (D.C. Cir. 1961). This case was based on a rulemaking proceeding dealing with the question whether or not to move a particular channel assignment from one locality to another. Certain parties were interested in the reallocation because they had applications for the channel pending in the event that it was reassigned. The court's order that a new proceeding be conducted to determine where and to whom the channel be assigned, id. at 743, thus applied strictly only to the rulemaking proceeding. The Commission in a new proceeding reallocated the channel, but stated in its order that it would not accept new applications. On appeal, in Fort Harrison Telecasting Corp. v. FCC, 324 F.2d 379, 386-87 (D.C. Cir. 1963), cert. denied sub nom. Sangamon Valley Television Corp. v. United States, 376 U.S. 915 (1964), the court held this part of the order error, on the basis of its remand order in the earlier case.

18345 F.2d 85 (D.C. Cir. 1965).

19348 F.2d 75 (D.C. Cir. 1965). 
in each of these cases was reversed because improper ex parte communications had been made to Commissioners by or on behalf of one of the applicants. ${ }^{20}$ In Sangamon, the procedure seems to have been employed as an extraordinary remedy based on unusual facts; ${ }^{21}$ in $W O R Z$ it became a rule. $W O R Z$ is particularly illustrative of the questions and problems involved in determining the rule's scope and its wisdom.

In June, 1957, the Commission awarded a license to construct and operate television channel 9 in Orlando, Florida, to Mid-Florida Television Corporation and denied the mutually exclusive application of the other applicant, WORZ. ${ }^{22}$ In July, 1963, after the award had been through many phases of litigation, ${ }^{23}$ the court of appeals vacated the award on the

20 The problem of ex parte communications in licensing awards became prominent in an investigation held by the Special Subcommittee on Legislative Oversight of the House Committee on Interstate and Foreign Commerce. See H.R. REP. No. 2711, 85th Cong., 2d Sess. (1959). Some of the work of the subcommittee is reported in a book by the first special counsel to the subcommittee. Schwartz, The Professor AND THE COMMISSIONS 74-112 (1959). The revelations in the subcommittee hearings of the way in which applicants were communicating with Commissioners off the record led to the Sangamon litigation and to two other well known cases. Massachusetts Bay Telecasters, Inc. v. FCC, 261 F.2d 55 (D.C. Cir. 1958), cert. denied sub nom. WHDH, Inc. v. FCC, 366 U..S. 918 (1961); WKAT, Inc. v. FCC, 258 F.2d 418 (D.C. Cir. 1958).

An interesting example of the ex parte communications problem is presented in a discussion of $W K A T$ in Rosenblum, How To Get Into TV: The Federal Commtmications Commission and Miami's Chamel 10, in THE USEs of Power 173 (Westin ed. 1962). For a discussion of the legal problems presented by ex parte communications see Peck, Regulation and Control of Ex Parte Communications With Administrative Agencies, 76 Harv. L. REv. 233 (1962); Note, 73 Harv. L. REv. 1178 (1960).

21 This judgment is based on the fact that reopening had not been required in the two earlier ex parte communications cases, Massachusetts Bay Telecasters, Inc. v. FCC, 295 F.2d 131 (D.C. Cir. 1961), and WKAT, Inc. v. FCC, 296 F.2d 375 (D.C. Cir.), cert. denied sub nom. Public Serv. Television, Inc. v. FCC, 368 U.S. 841 (1961). In Sangamon the Department of Justice had urged that "basic fairness" required reopening and the court agreed. Sangamon Valley Television Corp. v. United States, 294 F.2d 742, 743 (D.C. Cir. 1961).

22 WORZ, Inc., 22 F.C.C. 1254,1340 (1957).

23 The history of the case is as follows:

March 29, 1955-Record in case closed. Id. at 1255.

June 6, 1957-Award of license to Mid-Florida. Opinion considered misconduct by each applicant pertaining to WORZ's application: WORZ was found to have made a deliberate misstatement in its application; Mid-Florida was found to have attempted to mislead the Commission in the way it brought the misstatement to light; neither applicant was disqualified but a comparative demerit was given to WORZ in the affair. Id. at 1329-37.

May 15, 1958-Award affirmed by Court of Appeals for the District of Columbia Circuit. WORZ, Inc. v. FCC, 257 F.2d 199 (D.C. Cir. 1958) (per curiam).

October 27, 1958-WORZ's petition for certiorari granted. Court of appeals' decision vacated on information that ex parte representations had been made, possibly by Mid-Florida, to a Commissioner while the award was pending. WORZ, Inc. v. FCC, 358 U.S. 55 (1958) (per curiam).

May 21, 1959 -Commission ordered by court of appeals to investigate the alleged ex parte communications and make recommendations as to the proper disposition of the case. WORZ, Inc. v. FCC, 268 F.2d 889 (D.C. Cir. 1959).

January 3, 1963-Commission's report and recommendation released, finding that ex parte communications had been made on behalf of Mid-Florida, 
ground that ex parte representations had been made to a Commissioner on behalf of Mid-Florida. ${ }^{24}$ The court held that neither Mid-Florida nor WORZ was disqualified but ordered on remand that before the Commission make a new award to Mid-Florida or WORZ it hear oral argument and decide whether or not the public interest required that the record be opened to new hearings and new applications. ${ }^{25}$ The court directed that in making this determination the Commission consider the possibility that the record, then eight years old, might be "stale" and the fact that both applicants had been involved in improper conduct. ${ }^{26}$ This disposition differed from that in Sangamon. In that case the court itself decided that reopening was necessary. ${ }^{27}$ This difference is significant as indicating that in 1963 the court did not consider reopening to be a required procedure in ex parte communications cases. It is also particularly significant in establishing the scope of review under the Administrative Procedure Act of that decision on a subsequent appeal. The APA provides that matters of law are to be decided by the reviewing court and the matters invoking agency discretion are reversible only if found to be "arbitrary, capricious, an abuse of discretion, or otherwise not in accordance with law . . ."28 The implication of the order requiring the Commission to determine whether reopening was necessary would seem to be that the public interest did not require reopening as a matter of law, but that it could support a ruling by the Commission in exercise of its discretion either requiring or not requiring reopening. By saying that the question of reopening was a matter for the Commission, the court would seem to have limited its scope of review of the resultant decision to determining whether that decision

but that Mid-Florida's principals were not responsible. Recommended that award be vacated and case remanded for a new determination as between Mid-Florida and WORZ. WORZ, Inc., 22 Radio Reg. 125 (1963).

July 5, 1963-Court of appeals' decision that award must be vacated, saying that before making new award the Commission must decide question whether or not reopening of the record for new hearings and new applications might be required by the possible staleness of the record and the matters affecting the applicants' character qualifications. WORZ, Inc. v. FCC, 323 F.2d 618 (D.C. Cir. 1963), cert. denied, 376 U.S. 914 (1964).

June 12, 1964-New award of the license by the Commission to Mid-Florida, holding inter alia that the reopening was not required. WORZ, Inc., 36 F.C.C. 1535 (1964).

March 4, 1965-Award reversed by court of appeals. WORZ, Inc. v. FCC, 345 F.2d 85 (D.C. Cir. 1965).

November 17, 1965-Record opened by Commission for new applications to be filed before March 1, 1966. WORZ, Inc., 1 F.C.C. 2d 1377 (1965).

24 WORZ, Inc. v. FCC, 323 F.2d 618, 619 (D.C. Cir. 1963), cert. denied, 376 U.S. 914 (1964).

25 Significantly it did not require that evidence be taken on this issue, indicating that reopening was a matter of judgment rather than a question of fact. See note 38 infra.

26323 F.2d at 618.

27 Sangamon Valley Television Corp. v. United States, 294 F.2d 742 (D.C. Cir. 1961); see Fort Harrison Telecasting Corp. v. FCC, 324 F.2d 379 (D.C. Cir. 1963). $28 \S 10(\mathrm{e}), 60$ Stat. 243 (1946), 5 U.S.C. $\S 1009(\mathrm{e})(1964)$. 
was made arbitrarily or capriciously or in abuse of discretion. ${ }^{29}$ On the other hand, the remand might be interpreted as saying that while the question was basically a matter of law, the proper disposition was so unclear that the court, although fairly convinced that reopening was necessary, might nonetheless give weight to the Commission's interpretation of the law. ${ }^{30}$ Under this interpretation the Commission's decision would be reviewable as a question of law.

On remand the Commission decided that neither the age of the record nor the circumstances affecting the applicants' characters made reopening necessary. ${ }^{31}$ It then reevaluated the applications on the original record by the comparative criteria and again awarded the license to Mid-Florida. ${ }^{22}$ WORZ appealed, ${ }^{33}$ and the court of appeals reversed and remanded, directing the Commission to open the proceedings to new applications and to hold a new hearing. The reason given for the court's refusal to accept the Commission's decision not to reopen was a "nagging uncertainty" whether the public interest would be served by "confining the choice to these two applicants in the light of facts put on the record over ten years ago." 34 It was unclear from the opinion whether this uncertainty was related primarily to the issue of staleness, primarily to the improper conduct of the applicants, or depended substantially on both.

In this particularly unilluminating decision, reopening in ex parte communications cases became a rule. Its position was confirmed in a subsequent case, Jacksonville Broadcasting Corp. v. FCC,,$^{35}$ in which the court, citing $W O R Z$, ordered reopening as a matter of course.

The first question raised by $W O R Z$ is the technical status of the reopening issue. Section 10 of the APA gives a court reviewing agency action the power to decide questions of law, while limiting its review of decisions falling within the agency's discretion to "hold[ing] unlawful and set[ting] aside" those found to be "arbitrary, capricious, an abuse of discretion, or otherwise not in accordance with law . . . ."36 Since the court decided the question of reopening itself in the 1965 WORZ opinion as it did in Sangamon and Jacksonville, it would seem that it considered the decision whether to reopen a question of law. However the terms of the remand in the 1963 opinion raise serious doubts as to that view of the

$29 \mathrm{Ibid}$.

30 Cf. Bates \& Guild Co. v. Payne, 194 U.S. 106 (1904).

31 WORZ, Inc., 36 F.C.C. 1535,1537 (1964).

32 Id. at 1544 .

33 Although one contention in WORZ's appeal was that the Commission erred in failing to reopen the record, it was based on factors quite different from those which the court relied on to reverse. See Brief for Intervenor Mid-Florida, pp. 5-10; Brief for Appellee Commission, p. 29, WORZ, Inc. v. FCC, 345 F.2d 85 (D.C. Cir. 1965). Thus the court's reopening of the whole proceeding was sua sponte.

34 WORZ, Inc. v. FCC, 345 F.2d 85, 86 (D.C. Cir. 1965).

35348 F.2d 75, 81 (D.C. Cir. 1965).

$36 \$ 10(\mathrm{e}), 60$ Stat. 243 (1946), 5 U.S.C. $\$ 1009$ (e) (1964). The effect of $\S 402(\mathrm{~h})$ of the Communications Act of 1934,66 Stat. 720 (1952), 47 U.S.C. $\$ 402(\mathrm{~h})$ (1964), on the operation of this section of the APA is not clear. Under the APA the reviewing courts permitted action on finding an abuse of discretion is to "set aside" agency action. Section $402(h)$ may be read as giving the court power, beyond 
question, at least in the context of $W O R Z$, for the opinion was explicit that the decision to reopen was left to the Commission. The most plausible reading of that opinion, taken alone, is that the court decided in 1963 that the issue of reopening in WORZ was a matter for the Commission's discretion. ${ }^{37}$ But if this is true, the only ground on which the court could have properly reversed would have been a finding of abuse of discretion. ${ }^{38}$ If the court left the Commission with two alternatives-to reopen or not to reopen-then it seems clear that the Commission's choosing one rather than the other could not, in itself, be an abuse of discretion. The court could have found, however, that the decision on remand was arbitrary if it found that the Commission did not act in good faith in concluding not to reopen. ${ }^{39}$ Although the 1963 opinion left little doubt that the court expected that a full consideration of the question would show the necessity of reopening, ${ }^{40}$ the portion of the Commission's opinion dealing with the question is terse and conclusory. ${ }^{41}$ The court might have found that this indicated an incomplete or insincere consideration of the relevant factors and that the decision was therefore arbitrary. There are, however, objections to this interpretation of the decision. First, the court nowhere stated as a reason for its reversal that the Commission failed to consider the question properly. More important, there is no positive evidence in the record that the Commission was derelict in its consideration. However

simply reversing, to tailor its remand order, for example, to require specific additions to the record on remand. E.g., Clarksburg Publishing Co. v. FCC, 225 F.2d 511 (D.C. Cir. 1960). The limits on the court's power to "otherwise order" under $\$ 402$ (h) are unclear from the legislative history. See H.R. REP. No. 1750, 82d Cong., $2 d$ Sess. (1952). This section does not, however, alter the scope of review of discretionary actions, since $\S 402(\mathrm{~g})$ of the Communications Act provides that $\S 10$ of the APA is applicable.

37 See text accompanying note 29 supra.

38 It seems clear that the question was not one of fact. The 1963 opinion did not require the Commission to take new evidence. Moreover, reopening is not the kind of question which would seem to require new evidence. Therefore reopening was not a determination subject on review to the substantial evidence test provided for in the Administrative Procedure Act $\$ 10(\mathrm{e}), 60$ Stat. 243 (1946), 5 U.S.C. $\$ 1009$ (e) (1964).

39 This theory is suggested by a problem dealt with in Professor Jaffe's new book on administrative law under a chapter entitled "Remand-Utility or Futility?" Jaffe, Judicial Control of Administrative Action 589 (1965). Professor Jaffe there notes instances in which a court reversed an agency decision on the ground that the agency failed to consider a relevant factor, and the agency reached the same result on remand as it had originally, in a manner which suggested that it did not sincerely consider the factors it had been ordered to consider. SEC v. Chenery Corp., 332 U.S. 194 (1947); Sunbeam Television Corp. v. FCC, 243 F.2d 26 (D.C. Cir. 1957). In this situation a court on review may feel that its remand order was flouted, and was therefore "futile." Under the theory of WORZ here discussed the court, faced with what it believed to be such a situation, refused to let the agency get away with it.

40 WORZ, Inc. v. FCC, 323 F.2d 618, 619-20 (D.C. Cir. 1963). This judgment is emphasized in Judge Danaher's opinion concurring in the denial of WORZ's petition for rehearing en banc. Id. at 620-21.

41 Based upon the oral argument, the other matters of record herein, and the fact that neither of the applicants is disqualified from becoming a licensee, we believe that one of the existing applications now before us may be granted and that no necessity exists to reopen the record for new applications. Nor do we believe that the record of this proceeding is so stale that the filing of new applications should be permitted.

WORZ, Inc., 36 F.C.C. 1535, 1537 (1964). 
strong the court's feeling may have been, it had no solid ground on which to base a finding of arbitrariness : while the Commission's opinion is brief on this issue, there is no independent reason to believe that it did not result from proper consideration. In short, if the court thought that the question of reopening was one for the Commission's discretion, then its decision to reverse seems to have been technically improper under the APA, as it was based on no more than an unsupported suspicion of misconduct. If the court felt strongly that the Commission had defied its remand order, its reaction may be understandable, but it does not seem to be justified under the present rules defining the relationship between the court and the Commission.

On the other hand, if the 1963 remand did not really make reopening a matter of discretion ${ }^{42}$ the court may have reversed in 1965 because the reasons against reopening advanced by the Commission did not persuade the court to change its view of the proper application of the law.

In any event there is ambiguity surrounding the technical ground of the 1965 reversal, and consequently the status of the rule itself is not clear. For this reason it cannot be stated definitely whether the reopening rule is a rule of law in a technical sense or whether it represents only a standard by which the court in the future will determine whether the Commission has abused its discretion.

A more important problem arises in determining the scope of the rule. The one factor common to each of the three cases in which the rule has been applied, and which the court identified in each case as persuasive, was that the proceedings had been tainted by ex parte communications. Judge Burger's statement is typical of the reason stated for applying the rule in these cases: "When a regulatory agency so far departs from protecting the public interest [as to allow ex parte representations], some means must be found to ventilate the processes employed." 43 Although this may be an intuitively appealing approach to cases in which the agency is guilty of permitting misconduct, analysis shows that the "ventilation" explanation for the rule is not really responsive to the problem presented by ex parte communications. In each of these three cases the ex parte communications were made to Commissioners, not to hearing examiners. There is no suggestion in any of the cases that the record, compiled by the examiners prior to consideration of the applications by the Commissioners, was improperly compiled. The improper conduct which took place after the record was compiled is thus irrelevant to the soundness of that record, and provides in itself no reason to require a new record.

That part of the rule requiring acceptance of new applications seems equally unconnected with the problem presented by ex parte communications. The goal of "ventilation" seems to reflect a judgment that ex parte communications in the proceedings somehow affect the qualifications of the original applicants. The rule does not call for their complete disqualifica-

42 See note 30 supra and accompanying text.

43 Jacksonville Broadcasting Corp. v. FCC, 348 F.2d 75, 81 n.1 (D.C. Cir. 1965) (Burger, J., dissenting). 
tion on this ground, but it may effectively reduce their chances of success in a comparative sense. For example, when the record was closed in WORZ, each applicant had a mathematical chance of one out of two to obtain the license. On the remand following the 1965 decision, if two additional applications are received, these chances will be reduced to one out of four. It is difficult to see any justification for this result arising out of the problem of ex parte communications. To be sure, in any licensing proceeding the greater the number of applications, the greater are the chances that one of them will represent the "right" licensee for a particular community. But the practical necessity of awarding a license to someone within a reasonable time normally justifies the Commission's refusal to accept new applications after it has decided that the public interest is sufficiently represented by those received. There appears no reason in the ex parte communications cases for upsetting this decision. ${ }^{44}$ In each of the three cases the Commission assessed the effect of the ex parte communications on the qualifications of the applicants involved and decided that it was not sufficient to require disqualification; in each case the court approved this assessment. Thus, insofar as the rule's "ventilation" aspect is intended to work a penalty on applicants who, while not disqualifiable, have nonetheless been tainted by improper conduct, the rule indiscriminately affects both those original applicants who have not been guilty of misconduct and those whose misconduct has been adequately taken into account by the Commission. Furthermore, neither the Communications Act nor the APA gives a reviewing court the authority to penalize an applicant in this way. No reason, then, appears in any of these cases why, if the Commission, after reevaluating the applicants' qualifications in light of the ex parte incidents, decides that they nonetheless adequately represent the public interest, the court should as a general rule refuse to accept the Commission's decision.

Thus the theory of "ventilation," while perhaps superficially appealing, does not respond to the problem presented by ex parte communications. For no apparent purpose the rule renders worthless the entire investment of time and resources made by the Commission and the applicants in the previous proceeding, and by diluting the original applicants' chances to secure the license ignores any equity they might have developed in the award through their expenditure of effort.

In speaking of "staleness," 45 WORZ suggests a quite different rationale for the rule. The court's concern with the ex parte communications aspect of each of the cases ${ }^{46}$ suggests that staleness did not provide the motive for the development of the rule, but staleness does provide a more

44 It might seem that the rule may be justified as an effective means of preventing ex parte communications in the future. However, the rule did not develop as such until 1965; there is no indication in any reported case that ex parte contacts had been made with Commissioners since 1957. Consequently the problem which the rule was to solve seems to have no longer been a problem by the time the rule was developed. 45345 F. $2 \mathrm{~d}$ at 86.

46 Șee text accompanying note 43 supra. 
supportable justification for the rule. In all three cases the original record had been closed for a considerable period by the time reopening was ordered, ${ }^{47}$ which suggested to the court that the record might be stale, i.e., that it might not accurately represent relevant facts. It is not clear whether these inaccurately presented facts concerned the qualifications of the applicants or the nature and needs of the viewing community. The distinction is relevant to the justification for the rule.

The reopening rule does not seem an appropriate exercise of judicial control insofar as it is intended to reveal new facts concerning changes in the qualifications of the applicants brought about by the passage of time. As to this aspect of staleness, the normal rule that an agency's determination that a record need not be reopened will not be reversed by a reviewing court, ${ }^{48}$ seems the proper one. Any changes in the applicants which might have occurred over time will be presented to the Commission either on oral argument or by a motion by an applicant to reopen the record to accept the evidence of the specific changes. If the change is favorable it will be submitted by the changed applicant; if not, then the competing applicants may be expected to present it. Faced with such proffered evidence the Commission may then, in the individual case, decide whether the alleged change warrants reopening. ${ }^{49}$ This would seem a more effcient way of dealing with this type of change than a general rule requiring reopening, and more consistent with the statute's grant of discretion to the Commission. ${ }^{50}$

There is, however, another type of possible change brought about by the passage of time which might better be dealt with by a judicially created rule than by Commission discretion. The attempt of a licensing proceeding to determine the applicant most qualified to serve a particular community requires that the nature of the community-the size of its population, the nature of its economy and society, etc.-and its viewing needs be known. $^{51}$ These factors may be markedly affected by the passage of eight or ten years, particularly in rapidly changing parts of the country. If such

47 Although it is not completely clear from the various court and Commission reports, this period seems to have been nine years in Jacksonville, six years in Sangamon, and ten years in WORZ.

48 E.g., United States v. Pierce Auto Freight Lines, Inc., 327 U.S. 515 (1946); ICC v. City of Jersey City, 322 U.S. 503 (1944). In two recent appeals from decisions of the Subversive Activities Control Board requiring groups to register as communist front organizations, the Supreme Court refused to consider the cases on the merits and remanded, ordering the Board to make new determinations on the ground that the records on which the original decisions were made were stale. Veterans of the Abraham Lincoln Brigade v. Subversive Activities Control Bd., 380 U.S. 513 (1965) (per curiam); American Comm. for the Protection of Foreign Born v. Subversive Activities Control Bd., 380 U.S. 503 (1965). Because these cases involved constitutional questions of free speech and self-incrimination, they probably do not indicate any change in the rule of Pierce and Jersey City.

40 This decision is of course reviewable. See Southland Television Co. v. FCC, 266 F.2d 686 (D.C. Cir. 1959). In this situation, however, the Commission, not the court, has the primary responsibility for the decision; review is limited to the question of abuse of discretion.

50 FCC v. Schreiber, 381 U.S. 279, 289-91 (1965) ; FCC v. Pottsville Broadcasting Co., 309 U.S. 134, 138 (1940).

51 Cf. Easton Publishing Co. v. FCC, 175 .F.2d 344, 349 (D.C. Cir. 1949). 
changes have taken place in a particular community, they could very well make desirable the receipt of new applications from applicants perhaps more prepared to serve the changed community.

Perhaps even this sort of change should be dealt with by the Commission in each case rather than by a judicially imposed general rule. There is, however, at least one opposing argument. This sort of change is one not likely to be brought to the Commission's attention by the original applicants; ${ }^{52}$ it would not be in their interest to present facts which might lead the Commission to accept additional competing applications which would dilute their chances. Furthermore, the Commission, interested in bringing a prolonged case to a close, might itself tend to overlook the possibility of such change, and thus not make an independent effort to discover new facts.

Insofar as the foregoing theory justifies the rule, it does not restrict the application of the rule to cases involving ex parte communications, nor, for that matter, to television licensing proceedings.

Whatever may have been the court's rationale ${ }^{53}$ for formulating the rule, it presently exists, poorly explained and poorly defined. While it may be justified by reasons of policy, it seems inconsistent with the statutory design of putting primary responsibility for the award of licenses, and for establishing proper procedure to that end, in the hands of the Commission. ${ }^{54}$ A more illuminating judicial development of the rule might have indicated the intended limits on the rule, and thereby forestalled some of the questions raised by a rule which, insofar as it rests on a theory of "ventilating" tainted processes, is singularly inappropriate and which, insofar as it is based on considerations of staleness, contravenes a practice of not interfering with agency decisions on staleness long followed by the Supreme Court. ${ }^{55}$

52 Cf. Pinellas Broadcasting Co. v. FCC, 230 F.2d 204, 212 (D.C. Cir.) (Bazelon, J., dissenting), cert. denied, 350 U.S. 1007 (1956).

53 There is another superficially appealing theory for explaining the court's purpose in ordering acceptance of new applications. License awards are limited to a three year period, and new parties may file applications in the renewal proceeding. In WORZ such interested persons were precluded from filing applications over the ten year period during which the case had been in litigation. Arguably the purpose in ordering reopening was to give these persons the opportunity to be considered which they would have had if the award to Mid-Florida had become final earlier. This argument is weak because in practice once a party has won a license his application is almost always granted. See Richmond Television Corp. v. United States, 354 F.2d 410, 412 (4th Cir. 1965) (indicating that over a period of twenty-five years only $0.1 \%$ of such applications for renewal have been denied) ; Comment, 114 U. PA. L. REv. 386, 391 \& n.40 (1966).

54 Cases cited note 50 supra.

65 Cases cited note 48 supra. 